\title{
Energy Retrofit Potential Evaluation: The Regione Lombardia School Building Asset
}

\author{
Fulvio Re Cecconi, Lavinia Chiara Tagliabue, Nicola Moretti, \\ Enrico De Angelis, Andrea Giovanni Mainini and Sebastiano Maltese
}

\begin{abstract}
This chapter summarizes a long list of research activities aimed at defining a method to assess the retrofit potential of school buildings, based on maintenance needs, energy-saving potential, and the life cycle cost of the retrofitted building. New concepts are introduced as the gained comfort cost (GCC) as well as new methods are suggested as a probabilistic approach to describe users' behavior. Moreover, innovative methods as artificial neural networks have been employed to predict school buildings' energy performances. The GCC is a new key performance indicator employed to compare different retrofit strategies, focusing on a single classroom. Furthermore, the retrofit potential is evaluated also for the whole school building, exploiting building information modelling (BIM) to collect and transfer information to the building energy model (BEM). This method to analyze energy savings associated with the retrofit of a school building is combined with a method to manage and forecast the running costs of building stocks. The cost forecasting method has been validated through 11 case studies. Eventually, the scale is widened to all the school buildings in Regione Lombardia and the potential energy savings are computed by artificial neural networks (ANN) and Geographical Information Systems (GIS). These methods allow to evaluate energy retrofit potential of school buildings and their life cycle costs at different scales of intervention, from the single classroom to all the buildings in a region, allowing the public decision-maker to choose the best policy for retrofitting his school building stock.
\end{abstract}

Keywords Energy retrofit · Data-driven process • Artificial Neural Networks $(\mathrm{ANN}) \cdot$ Geographical Information System (GIS)

F. Re Cecconi $(\varangle) \cdot$ N. Moretti · E. De Angelis · A. G. Mainini

Architecture, Built Environment and Construction Engineering-ABC Department,

Politecnico di Milano, Milan, Italy

e-mail: fulvio.rececconi@polimi.it

L. C. Tagliabue

Department of Civil, Environmental, Architectural Engineering and Mathematics-DICATAM,

University of Brescia, Brescia, Italy

S. Maltese

Institute for Applied Sustainability to the Built Environment, University of Applied

Sciences and Arts of Southern Switzerland-SUPSI, Canobbio, Switzerland

(C) The Author(s) 2020

S. Della Torre et al. (eds.), Buildings for Education, Research for Development,

https://doi.org/10.1007/978-3-030-33687-5_27 


\section{Introduction}

Although educational buildings account for about more than $4 \%$ of the European built stock in terms of net floor area (even less, about 3\%, in terms of energy consumption, BPIE 2011, and little more than 1 MToe, following Citterio and Fasano 2009), they represent a critical asset: because of their age and maintenance needs; even more, because of their influence in the learning performance of their students.

Comfort, safety and security conditions, have a strong influence on the learning process. The learning performances (Chatzidiakou et al. 2014; BB90 2014; BB93 2014; BB101 2006) report a possible upgrade from 16 (average) to 50\% in learning rate if adequate air quality and natural lighting are provided. European buildings are old (ENEA FIRE 2012) and, although slightly less aged than the average built asset, educational buildings are even less "updated" than others. This is particularly true in Italy, where more than 40,000 buildings hosting the more than 52,000 Italian public educational institutions (Source: MIUR Open Data: an older estimation, Citterio and Fasano 2009, accounted about 43,000 buildings, from other sources) have been poorly retrofitted and maintained, in the last 50 years and scarcely adapted to innovative teaching models. Analyzing the recent open dataset provided by the Italian Ministry of Education (about 2017/2018 teaching session), we can report that more than $17 \%$ of them is considered fully outdated ("vetusto"); more than $20 \%$ are lacking any basic analysis of their risks and safety issues and, most important, among those located in a high (Zone I) or medium/high (Zone II) seismicity area, about $80 \%$ of them have not been analyzed even only from a seismic point of view.

In a less recent document about possible actions on the Italian educational building stock (ENEA 2012), the percentage of the number of buildings highly needing a retrofit was estimated as higher than $35 \%$. In any case, $75 \%$ of actual school building dates back before any Italian energy laws (1976).

Very few of them (less than 10\%) have been retrofitted to empower their acoustical performances (but a clear analysis of the acoustical needs is widely lacking, also in highly disturbed areas); only $5 \%$ of actual school buildings have been fully (envelope and plants) retrofitted to enhance their energy efficiency (mainly to achieve a basic C-level energy label ${ }^{1}$ ) and no more than $25 \%$ have been only partly refurbished, with scarce impact on energy needs.

The following paper reports the main results of some recent studies, performed by the authors, about the effects of school building retrofitting: how to evaluate

\footnotetext{
${ }^{1}$ A C-level building, in the context of the European EPBD European Directive 2010/31 (Energy Performance of Buildings Directive-EPBD) and 2018/844 practice, is a building, in a specific climatic condition, that consumes as the "average building", i.e. the benchmark of all the building realized as prescribed by the national/regional standards before EPBD. An A-level building is a better-more efficient-one, that consumes less than $50 \%$ of the $C$-level benchmark.
} 
them, their feasibility and potential, and the data sources we can access and organize to enforce the evidence of our understanding, either for a more general, strategic decision, or for the optimization of a specific case study.

\section{How to Assess Comfort and Real Energy Needs}

The evaluation of the real energy needs of a building is a fundamental step to reliably assess the potential annual savings and the payback time of investment of a retrofit strategy. The real energy needs are highly influenced by the real building use, which is the main issue when an extended time of use (beyond main teaching activity) is promoted. The occupancy profiles and users' habits can help to predict the variability of the energy performance of the building (Tagliabue et al. 2016). Moreover, the occupants' awareness about energy use combined with low-cost strategies has an estimated 20\% effectiveness on energy reduction (ENEA 2012), especially in case of total replacement or integration of thermal plants and without smart control devices. Italian school buildings are mainly equipped with heating systems for winter, avoiding cooling systems for summer, however, climate changes and the extended use of the buildings entail the need of mitigation measures for overheating in the middle and summer seasons. In this paper, refurbishment strategies referred to an adaptive comfort approach are mainly proposed, considering the building envelope as a passive control system of the indoor conditions. Moreover, since 2009 (DPR 59/09) national regulations introduced dynamic thermal properties to be assessed for building envelope in order to reduce and effectively control the heat gains (Decreto Interministeriale 2015). In any case, the bioclimatic approach encompasses evident advantages such as a lean and cost-effective implementation in addition to its affordability. Measurement for commissioning and dynamic simulations is crucial to define quantitative advantages of bioclimatic design strategies; nevertheless, they are complex and time-consuming due to the amount of hourly data that are managed and finally the passive behavior of a building is not effortlessly synthesized. A comparison of hourly consumption can be used for air-conditioned buildings; meanwhile, buildings with no active thermal control in summer need more sophisticated statistical analyses to account for the thermal inertia effect (Di Perna et al. 2011).

\section{Average Building School Conditions and Related Performances}

The retrofit of the envelope and the thermal plants of a building can heavily reduce the energy consumption and the associated running costs of a building. The investment costs, therefore, may be compensated by the running cost reduction for refurbishment 
Table 1 Frequently adopted envelope typologies for the Italian school building stock

\begin{tabular}{l|l|l}
\hline Opaque envelope component & $U_{\text {factor }}\left[\mathrm{W} / \mathrm{m}^{2} \mathrm{~K}\right]$ & $Y_{\text {ie }}\left[\mathrm{W} / \mathrm{m}^{2} \mathrm{~K}\right]$ \\
\hline $\begin{array}{l}\text { ROOF: Flat with reinforced brick-concrete slab, } \\
\text { low insulation }\end{array}$ & 1.01 & 0.19 \\
\hline $\begin{array}{l}\text { WALL: Hollow brick masonry, low insulation } \\
(25 \mathrm{~cm})\end{array}$ & 0.80 & 0.19 \\
\hline $\begin{array}{l}\text { WALL: Hollow brick masonry, low insulation } \\
(40 \mathrm{~cm})\end{array}$ & 0.76 & 0.06 \\
\hline $\begin{array}{l}\text { FLOOR: with reinforced brick-concrete slab, low } \\
\text { insulation }\end{array}$ & 0.98 & 0.19 \\
\hline FLOOR: Concrete floor on soil, low insulation & 1.24 & 0.11 \\
\hline \begin{tabular}{l} 
Transparent envelope component \\
\hline Double glass, air-filled, wood frame
\end{tabular} & $U_{\text {factor }\left[\mathrm{W} / \mathrm{M}^{2} \mathrm{~K}\right]}$ & $\mathrm{SHGC}\left[\mathrm{W} / \mathrm{M}^{2} \mathrm{~K}\right]$ \\
\hline $\begin{array}{l}\text { Double glass, air-filled, metal frame without thermal } \\
\text { break }\end{array}$ & 3.7 & 0.75 \\
\hline
\end{tabular}

interventions, that are more cost competitive when associated with envelope and plant maintenance due to their physical or technical obsolescence.

$70 \%$ of the school buildings have reinforced concrete frame structure, brick infill walls and are equipped with gas boiler systems for heating (average efficiency $\eta \leq$ 0.9). In any case, for buildings realized after the L. 373/76 was established, a thin insulation layer in the opaque envelope can be expected. Focusing only on the schools built from 1976 to 1990 , the average and most frequently adopted envelope typologies in Italian school buildings are presented in Table 1 to define the framework in which the envelope technologies and thermal properties of the simulation baseline scenario are limited. The main reported parameters are: $U$-factor is the thermal transmittance, $Y_{\text {ie }}$ represents the periodic thermal transmittance value and SHGC is the solar heat gain coefficient.

It is worthy to note that, in addition to thermal transmittance for both transparent and opaque envelope, and solar heat gains control strategies, a suitable level of thermal inertia is crucial to improve comfort conditions and energy savings in particular when adaptive thermal comfort models are assumed. Depending on the calculation methodology, the building type and use (Aste 2009; Karlsson 2013), the influence of the inertia in the thermal behavior of a building can vary from 30 to $80 \%$.

In old school buildings where the transparent/opaque envelope surface ratio is low, the effect of thermal inertia decreases while air change rate and permeable coverings interact more efficiently with a time constant and energy saving (Di Perna et al. 2011). Nevertheless, thresholds of suitable internal areal heat capacity related to periodic thermal transmittance $\left(Y_{\mathrm{ie}}\right)$ have also been defined for school buildings envelopes ranging between $50 \mathrm{~kJ} / \mathrm{m}^{2} \mathrm{~K}$ for $Y_{\text {ie }} \leq 0.04 ; 70 \mathrm{~kJ} / \mathrm{m}^{2} \mathrm{~K}$ for $0.04 \leq Y_{\text {ie }} \leq$ 0.08 and $90 \mathrm{~kJ} / \mathrm{m}^{2} \mathrm{~K}$ for $0.08 \leq Y_{\text {ie }} \leq 0.12$. 


\section{Assessing the Gained Comfort Cost}

The methodology adopted in the present study focuses on the assessment of the thermal indoor conditions into a representative unit or classroom of a school building in northern Italy, equipped with traditional envelope (Table 1) and compared to improved scenarios including refurbishment strategies.

The base case has been compared with five improved alternatives with different energy retrofit strategies for enhancing energy performances and improving indoor thermal comfort (Table 2).

The results are based on four levels of intervention, from micro (single class in a school building) to macro (school building stock in the Lombardy region). The analyses have been carried out according to different methodologies ranging from the simple dynamic analysis of energy performance to statistical evaluation of the result to forecasting methods based on neural networks.

The simulation test cell is a single classroom in the south oriented with three identical windows $(1.25 \times 2.5 \mathrm{~m})$ on the only wall-facing outdoors. The energy saving retrofit strategies (Table 2) and the variation in associated costs GCC are represented by the segments in the graph in Fig. 1 for winter (blue lines) and summer (yellow lines).

The assessment is based on the hourly indoor air temperature as a comfort parameter under free-floating conditions. The LCC has been calculated for six cases to show how the cost categories (i.e. construction, operation, maintenance) influence the total cost. The installation cost is proportional to the maintenance cost, while operational energy costs are related to the performance of the component. The energy cost has a predominant role because installation and maintenance costs are strictly related to the envelope (opaque and transparent). In case of installation and maintenance, if the costs of different components (e.g. finishing, floor, partitions, and systems) would be included, the ratio would change. The preventive maintenance strategy has been chosen, as more convenient than the corrective strategy.

Figure 1 shows the cost for achieving one unit of comfort. This is done comparing the LCC and the comfort (in winter and in summer) for each alternative with the base case. According to the LCC ( $Y$-axis), the best solutions are the positive ones, with an LCC lower than the base case. According to the comfort ( $X$-axis), the best solutions

Table 2 Tested combinations of energy-saving retrofit strategies

\begin{tabular}{l|l|l|l|l}
\hline No. & Evaluated test case & $U_{\mathrm{av}} \mathrm{W} / \mathrm{m}^{2} \mathrm{~K}$ & $U_{\mathrm{w}} \mathrm{W} / \mathrm{m}^{2} \mathrm{~K}$ & SHGC $[-]$ \\
\hline 1 & Base case & 0.96 & 2.8 & 0.75 \\
\hline 2 & Improved $U_{\mathrm{w}}$ & 0.96 & 1.0 & 0.50 \\
\hline 3 & Improved $U_{\mathrm{w}}$ and SHGC & 0.96 & 1.0 & 0.35 \\
\hline 4 & $U_{\mathrm{av}}$ reduced & 0.29 & 2.8 & 0.75 \\
\hline 5 & $U_{\mathrm{av}}$ and $U_{\mathrm{w}}$ reduced & 0.29 & 1.0 & 0.50 \\
\hline 6 & Best case & 0.29 & 1.0 & 0.35 \\
\hline
\end{tabular}




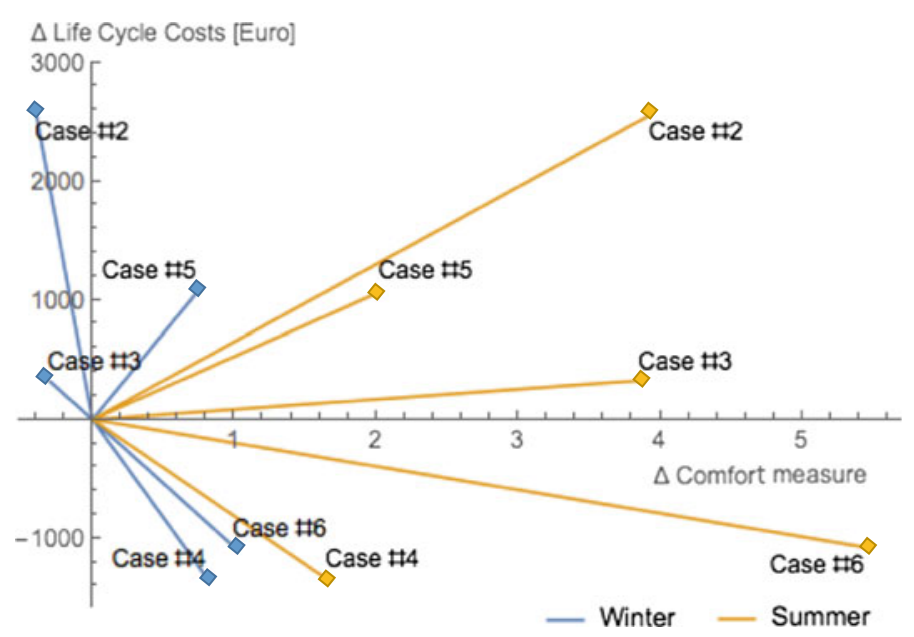

Fig. 1 Gained comfort cost variation graph (Tagliabue 2017)

are the most distant from the origin; a negative value means that the alternative has a lower comfort than the base case. According to what was mentioned above, case 6 (best case) is the most suitable in terms of comfort, while case 2 is the most suitable in terms of LCC.

\section{Retrofit Potential of a School Building}

At building-level we considered, as a case study, a primary school located in northern Italy, in Nerviano, Milan province, built in the 1950s and not refurbished except for the ordinary maintenance operations. The occupants, both students and staff are estimated at around 400 people. The floor area is around $3000 \mathrm{~m}^{2}$ counting classrooms spaces, toilets, multi-task rooms, offices and canteen. A BIM model has been created on the documental data and information derived by a survey. Each building envelope component identified during the survey has been modeled in terms of thickness and materials (Table 2). The internal height has been assumed based on external measures and standard height for the built environment $(\sim 3 \mathrm{~m})$. A BIM model was used to define retrofit intervention related to pathologies and costs have been deduced. Furthermore, the BIM model could be connected to Facility Management (FM) software. The EnergyPlus simulations result has been used to calculate a cost simulation for a retrofit intervention of Exterior Insulation and Finishing System (EIFS).

Owing to the need to refurbish the facade, one or more energy retrofitting alternatives can be evaluated on the same components:

(a) Replacement of windows and doors with a more thermally resistant model; 


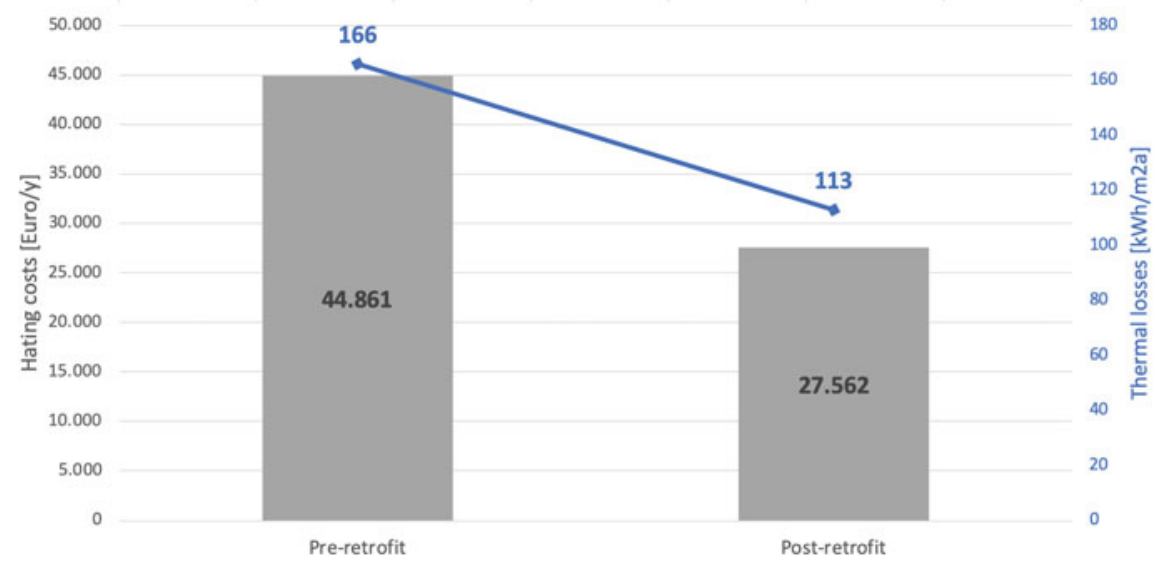

Fig. 2 Economic results comparison: Thermal losses and cost (Tagliabue 2017/2)

(b) Replacement of the external layer with an EIFS to be applied on an existing wall.

The thermal loss decrease has been calculated as $-38 \%$, calculated on the opaque envelope (Fig. 2). Therefore, the main results are listed as follows:

(c) Envelope refurbishment cost: $108,284 €$

(d) Total retrofit cost: $222,925 €\left(\sim 75 € / \mathrm{m}^{2}\right)$

(e) Annual saving: 17,299 €/year $(\sim-38 \%)$

(f) Payback time: $\sim 5$ years

\section{Managing Running Costs Data of a Portfolio of School Buildings}

The analysis focused on how expenses for schools were managed in the Municipality of Seregno pointed out the main lack: there was no management system. Expenses were forecast without exact knowledge of how much was spent the previous year, no records were taken on who did what and how much was paid for maintenance operation except for paper documents that were collected, stored and never used anymore. Seregno's 11 school buildings expenses bills are stored in paper documents archived in folders in different offices of the Municipality.

All the data acquired and elaborated had been used to implement predictive models for future expenses (heating and gas, electricity, maintenance) to solve one of the main municipality's problem - the reliability of costs forecast. The following figure shows, for example, the linear model to be used to predict heating and gas expenses for school "Rodari". Models like this one are available to the municipality for each school and for all the three types of expenses (Fig. 3). 


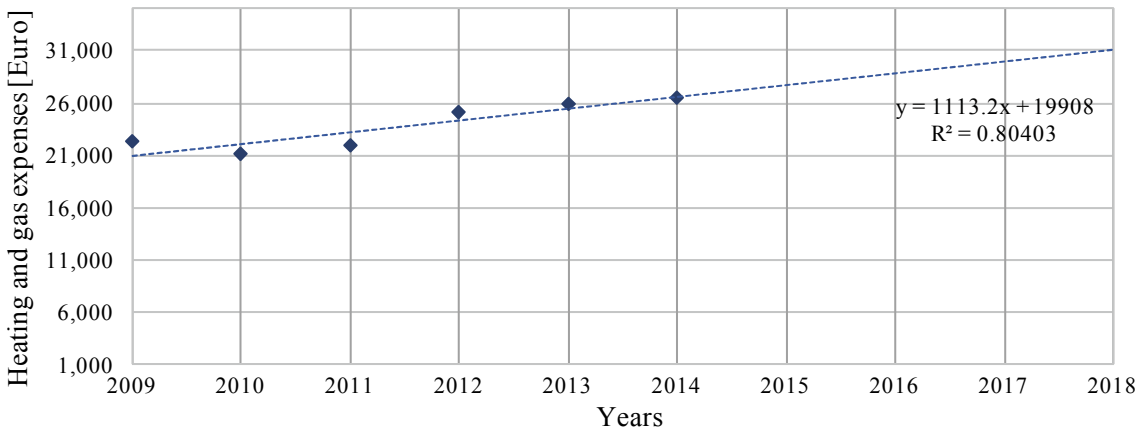

Fig. 3 Example of a predictive model for energy costs (school "Rodari")—(Re Cecconi et al. 2017)

\section{Evaluate Retrofit Potential in Regione Lombardia's School Buildings}

The last results are included within a regional level framework. The implementation of the set of methods proposed through this research starts from a specific dataset: the CENED DB provided by Regione Lombardia. This DB includes all the energy labels provided by the accredited professional in the Lombardy region. CENED open data have been used to train a set of multi-layer feed-forward ANN that proved to be reliable instruments to forecast energy performance of school buildings. School buildings have been analyzed and classified according to their age (in an overall time span of more than one century) and performance of their envelope. This process gave as an outcome the definition of homogeneous classes of comparable school buildings. For each class, specific retrofit strategies, suitable for their characteristics, have been defined and the potential energy savings have been computed through the trained ANN. The output data have been imported in a GIS environment, through which it has been possible to carry out a spatial analysis for the whole Lombardy region territory. Although there is a gap between actual and ANN-computed performance, the proposed process balances the reliability of energy savings forecasts, with the necessity of saving time and resources to carry out the estimation. A more precise energy demand estimation method would be certainly too expensive to be applied on an extended school buildings stock. Moreover, the proposed method allows to easily spot the most convenient retrofit strategy for the whole portfolio, even in the very early stage of the decision-making process (Fig. 4). 


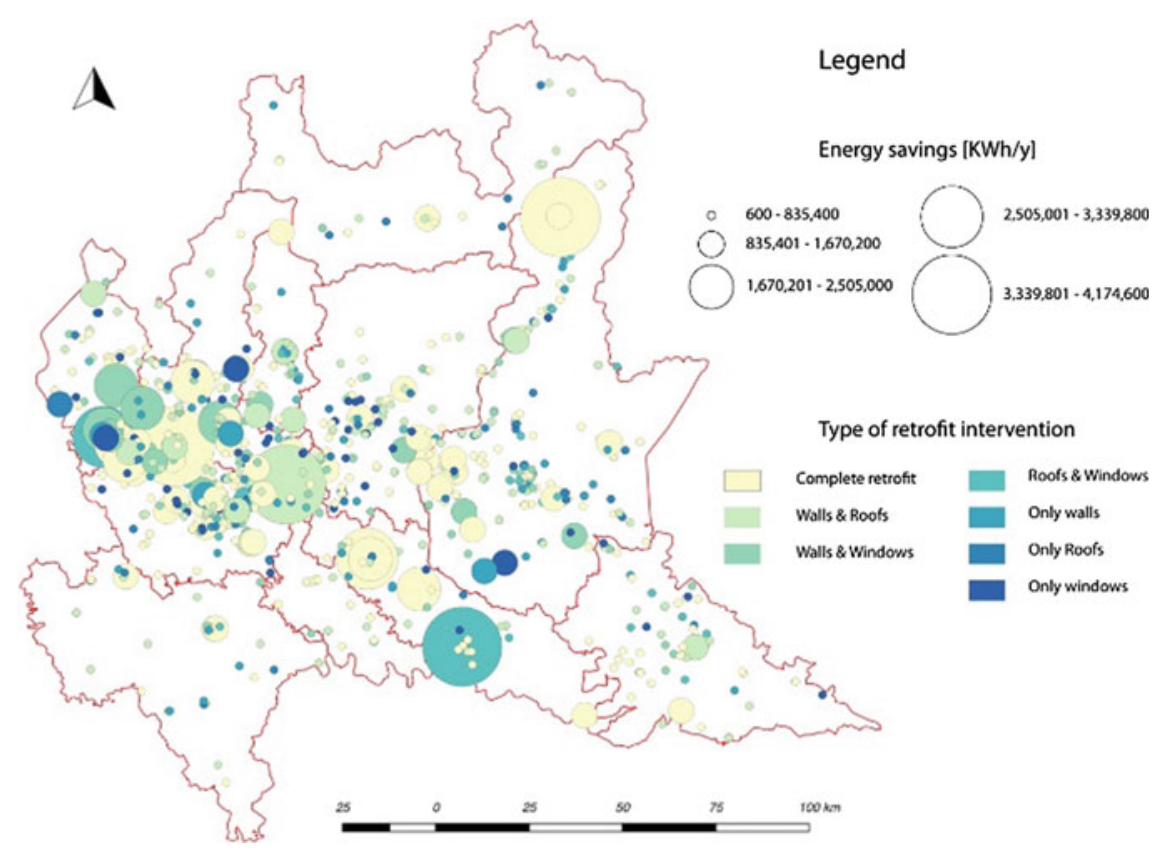

Fig. 4 ANN computed energy savings by type of intervention in the Lombardy region. (Re Cecconi et al. 2019)

\section{Conclusions}

The main barriers to the effective recovery of existing school buildings are the lack of a coherent and comprehensive methodology to address the process and an everlimited intervention budget. To overcome this situation, it is necessary to structure the decision-making process, as well as prioritize the choice of interventions according to a multi-stage matrix that is able to guide interventions and satisfy the different stakeholders involved during the process. Likewise, it will be equally important to support the creation of new financial instruments and sources of funding. It is evident that it is not possible to evaluate only the aspect of costs as a driver for decision-making. During the last few years, the improvement of the building's energy efficiency has been a very important lever not only to raise funds but also to stimulate the renovation of existing school buildings. The reason for this choice lies in the immediate perception of the economic return due to the sudden reduction in consumption, which translates into lower maintenance and operating costs for the municipal administration. In some cases, some interventions were the occasion to focus also on the improvement of the building seismic performance, which sometimes is underestimated but that in particular areas can strongly affect the safety of the people work in and studying in these spaces. On the other hand, new teaching and learning methods require a modified use of the school spaces, able to accommodate of daily changes, 
reaching the maximum flexibility for teaching and learning activities. At the same time, this need of flexibility should relate to added building envelope and systems capabilities, for example, by the use of natural ventilation and daylighting or the use of low-temperature heating systems, increasing the need of monitoring indoor quantities and fostering a continuous commissioning approach.

Further development of the research will focus on new functional requirements, which combine energy-related as well as functional, and maintenance measures.

\section{References}

BPIE (2011) aa.vv. Europe's buildings under the microscope, 2011, here

Building Bulletin BB90 (2014) Lighting design for schools. Education Founding Agency, 11 March 2014. https://www.gov.uk/government/publications/building-bulletin-90-lighting-designfor-schools

Building Bulletin BB93 (2014) Acoustic design of schools-performance standards. Education Founding Agency, 19 December 2014. https://www.gov.uk/government/publications/acousticslighting-and-ventilation-in-schools/acoustics-lighting-and-ventilation-in-schools

Building Bulletin BB101 (2006) Ventilation of school buildings, version 1.4-5th July 2006. https:// www.gov.uk/government/publications/acoustics-lighting-and-ventilation-in-schools/acousticslighting-and-ventilation-in-schools

Chatzidiakou L, Mumovic D, Dockrell J (2014) The effects of thermal conditions and indoor air quality on health, comfort and cognitive performance of students. The Bartlett, UCL Institute for Environmental Design and Engineering London, here

Citterio M, Fasano G (2009) Indagine sui consumi degli edifici pubblici (direzionale e scuole) e potenzialità degli interventi di efficienza energetica, ENEA, Report RSE/2009/165

Decreto Interministeriale 26 giugno (2015) Applicazione delle metodologie di calcolo delle prestazioni energetiche e definizione delle prescrizioni e dei requisiti minini degli edifici, Supplemento Ordinario alla Gazzetta ufficiale n.162 del 15 luglio 2015

Di Perna C, Stazi F, Ursini Casalena A, D'Orazio M (2011) Influence of the internal inertia of the building envelope on summertime comfort in buildings with high internal heat loads. Energy Build 43(1):200-206

Directive 2010/31/EU of The European Parliament and of the Council of 19 May 2010 on the energy performance of buildings (recast), Off J Eur Union L 153/13

Directive (EU) 2018/844 of the European Parliament and of the Council of 30 May 2018 amending Directive 2010/31/EU on the energy performance of buildings and Directive 2012/27/EU on energy efficiency. Off J Eur Union

DPR 59/2009 Regolamento di attuazione dell'articolo 4, comma 1, lettere a) e b), del DLgs 192/05 concernente attuazione della direttiva 2002/91/CE sul rendimento energetico in edilizia

ENEA-FIRE (2012) Guida per il contenimento della spesa energetica nelle scuole

Legge 30 aprile 1976, n. 373 Norme per il contenimento del consumo energetico per usi termici negli edifici

Re Cecconi F, Tagliabue LC, Sebastiano M, Ciribini ALC, De Angelis E (2017) A performance based management system for cost prediction suitable for school building stock, ISTeA 2017Re-shaping the construction industry

Re Cecconi F, Moretti N, Tagliabue LC (2019) Application of artificial neutral network and geographic information system to evaluate retrofit potential in public school buildings. Renew Sustain Energy Rev 110:266-277

Tagliabue LC, Manfren M, Ciribini ALC, De Angelis E (2016) Probabilistic behavioural modelling in building performance simulation—-the Brescia eLUX lab. Energy Build 128:119-131 
Tagliabue LC, Mainini AG, Re Cecconi F, Sebastiano M, De Angelis E, Zani A (2017) Thermal and economic efficiency of progressive retrofit strategies for school buildings by a statistical analysis based tool (2017), IBPSA 2017—building simulation 2017 conference

Tagliabue LC, Sebastiano M, Re Cecconi F, De Angelis E, Ciribini ALC (2017) Integrated design and modelling-based smart school concept to renovate the existing school building sector (2017) ISTeA 201-Re-shaping the construction industry

Open Access This chapter is licensed under the terms of the Creative Commons Attribution 4.0 International License (http://creativecommons.org/licenses/by/4.0/), which permits use, sharing, adaptation, distribution and reproduction in any medium or format, as long as you give appropriate credit to the original author(s) and the source, provide a link to the Creative Commons license and indicate if changes were made.

The images or other third party material in this chapter are included in the chapter's Creative Commons license, unless indicated otherwise in a credit line to the material. If material is not included in the chapter's Creative Commons license and your intended use is not permitted by statutory regulation or exceeds the permitted use, you will need to obtain permission directly from the copyright holder. 